\title{
A comprehensive typology of philosophical perspectives on Qohelet
}

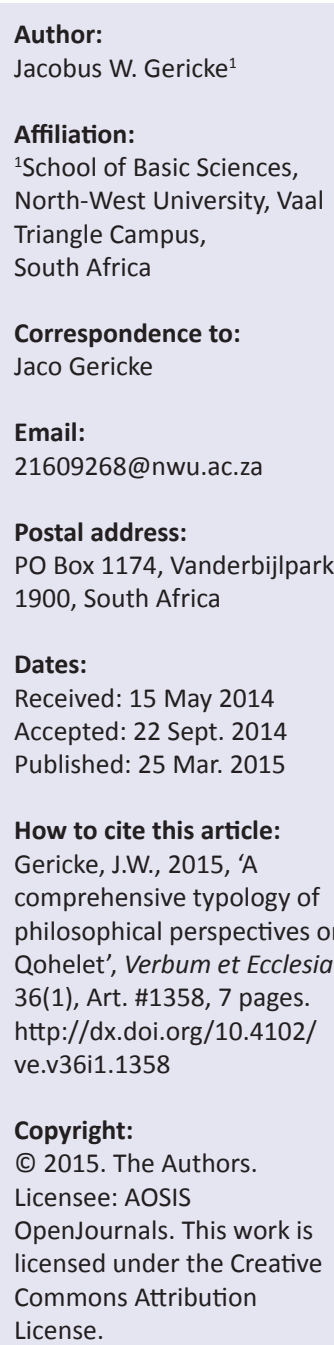

Read online:

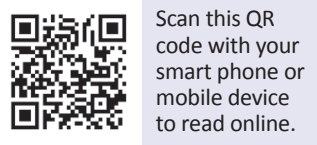

In this article, the author seeks to provide the first comprehensive typology of philosophical approaches to the book of Qohelet (Ecclesiastes). Six overlapping, yet functionally distinct, meta-philosophical categories are identified, namely (1) general philosophical profiling, (2) ancient philosophical comparisons, (3) modern philosophical comparisons, (4) topical philosophical exegesis, (5) philosophical reception histories and actualisations and (6) antiphilosophical readings. The conclusion of the study is that research on Qohelet in relationship to philosophy is quantitatively more complex and multifaceted than traditional overviews tend to show.

Intradisciplinary and/or interdisciplinary implications: This study challenges the context of currently available perspectives on Qohelet in relationship to philosophy, resulting in the provisioning of a quantitatively more functional framework for meta-philosophical commentary, which in turn both demands and makes possible a change in the way philosophical approaches to the text are construed.

\section{Introduction}

Within the genre of meta-commentary on the Hebrew Bible or Old-Testament book of Qohelet (or 'Ecclesiastes'), a variety of overviews exists, outlining the history of specific types of interdisciplinary perspectives on the book (cf. e.g. Bartholomew 1998; Barton 1996; Crenshaw 1983:41-56; Christianson 2007; Sneed 2012:3-73). Most common in the literature are summaries of linguistic, literary, historical, social-scientific and theological approaches preceding further specialised discussion. What is still absent from scholarly research is a comprehensive and systematic overview of all the various ways in which Qohelet has been read in relationship to philosophy in all its multiple manifestations.

Tobe sure, meta-philosophical perspectives on Qohelet are not altogether absent from the literature, and three kinds are commonly encountered. Nearly all major mainstream commentaries contain sections featuring critical evaluations of ways in which Qohelet has been read in relationship to ancient Greek philosophy, modern existentialist philosophy and various hermeneutical theories. Even so, no overview exists that draws together all of the available data under 'philosophical perspectives or approaches' analogous to the way in which it is done in connection with other methodologies. In addition, philosophical readings are seldom if ever discussed for their own sake and tend to be assimilated to and subsumed under linguistic, historical-critical and theological assessments.

The state of affairs noted above is somewhat perplexing, given the near universal consensus that the book is the closest that the Hebrew Bible comes to being, in some sense, 'philosophical' (in the popular Western sense of the concept). It is also strange given the perennial controversies concerning attempts to see Qohelet in relationship to some or other philosophical tradition. In light of this, this article aims at providing a comprehensive, descriptive and historical thematic typology of philosophical and quasi-philosophical perspectives on Qohelet. This will be supplemented by a brief discussion pertaining to the question of which philosophical perspective on Qohelet can be considered most useful.

The kind of discussion envisaged here, of course, cannot be exhaustive since the very question of what counts as a philosophical approach (over and against, say, a post-modern literary or sociological approach) is not always clear. In addition, it should be noted that the discussion below may prove somewhat hard to follow for those who are not familiar with research on the book of Qohelet and the philosophical jargon involved. Whilst this is likely to limit the appeal and audience of the article, it is hoped that its contents will nonetheless be of interest and use to specialists. 


\section{A new typology of philosophical perspectives}

Below follows a series of categorisations of exemplary ways in which Qohelet has been related to philosophy. The treatment is thus structured thematically although the relevant research is diachronically arranged under the various rubrics. Whilst aspiring to aid in the identification of and distinguishing between philosophical approaches to Qohelet, the discussion does not pretend to deliver either a necessary or exhaustive outline. On the one hand, alternatively structured typologies are most certainly possible. On the other hand, spatial limitations preclude me from being able to list and attend to all possible related research and its detail. Ultimately, the dissemination involves the following generalising classification of presumably representative exemplars:

- general philosophical profiling (classifications)

- ancient philosophical comparisons (various contexts)

- modern philosophical comparisons (various contexts)

- philosophical exegesis (various philosophical [sub-] disciplines and their loci)

- philosophical reception histories and actualisations (applied philosophy)

- anti-philosophical readings (attempted dissociations from philosophy).

This format is admittedly not without its drawbacks, not least because categories frequently overlap, thus sometimes making both particular locations and placements to appear potentially arbitrary. This is unavoidable due to the nature of the research dealt with, which does not allow for a single clear-cut representation. Hence categories are of necessity fuzzy.

\section{Philosophical profiling}

The first type of research involves general philosophical profiling, that is, casting Qohelet's thought as a basic philosophical stance. Given the vicissitudes of the chosen historical context, this category inevitably overlaps with ones below featuring comparisons with ancient and modern philosophies. Yet philosophical profiling qua type warrants separate construction, given that the main concern here is not to compare Qohelet's similarities and differences with any particular philosophical tradition, but instead to identify the generic philosophical mind-set of the implied author(s). In this category, then, are classifications of the book of Qohelet as representing a particular type of philosophical genre (cf. Anderson 1998:289-300).

Of course, the most popular general folk-philosophical profiling suggests that Qohelet was a 'philosopher' in the literal-etymological Greek sense of being a 'lover of wisdom' (cf. Gericke 2013a:344-357). Equating wisdom with philosophy, although potentially controversial in biblical scholarship (where wisdom is typically seen as preceding and being conceptually distinct from philosophy), has a long tradition going back to Parmenides and Aristotle (who admittedly reduced it to practical philosophy). Yet this view has once again come to be in vogue, especially within some quarters of so-called historical 'minimalism' and their Hellenistic Hebrew Bible (see Davies 2011:160-164; Thompson 1999:passim).

However, viewing Qohelet as a philosopher is not as atypical amongst specialists on the book as one might expect. For example, several studies actually revolve around the use of the title of generic philosopher to classify the implied author (see, chronologically, e.g. Nordheimer 1838:197-219; Lohfink 1990:20-25; Stefani 1995:393-409; Richter 1998:435449; Hohnjec 2002:333-351). In many of these cases, the designation 'philosopher' is, however, used equivocally, that is, Qohelet is deemed to be a philosopher in both the technical and folk-philosophical senses.

The same tendency for equivocation is also found in more specific profilings. In this regard, the first and most durable popular classification given to either the book or the author pertains to its supposed Epicureanism (see e.g. Bartholomew 2009:55; Barton 1908:38; Fox 1989:16). This already occurs in ancient rabbinic disputes about the canonicity of the book which show reservations regarding its status, given supposedly 'Epicurean' (i.e. heretical) tendencies in verses commending pleasure as opposed to piety (e.g. 2:24; $3: 12-13 ; 3: 22 ; 5: 18 ; 8: 15)$. Technically, this is 'Epicurean' in the unhistorical populist sense of connoting a hedonistic devotion to the pursuit of pleasure, something absent from the actual philosophy of Epicurus and his followers. Overall, however, this particular profile has fallen out of favour in scholarly research and remains a problem only addressed by religious apologists.

Closely related to the above is research linking the ideas in the book to Stoicism. This profile seems warranted in view of Qohelet's seeming equanimity in the face of both good and evil in certain social-psychological contexts. Sometimes, a mixture of philosophical profiles can be found in the related research, for instance when the contradictions within the book was explained to be the result of conflicting influences from Epicureanism and Stoicism combined (e.g. Tyler 1899:30-32). A more recent, yet somewhat dated, review profiling Qohelet as Stoic and/or anti-Stoic is the study by Gammie (1985:169-187). However, relating the book to Stoic philosophy has basically fallen out of favour.

Another ancient profile constructed and imposed onto Qohelet was, of all things, Platonism. This occurred particularly in early Christian allegorical-philosophical readings of the book. Perhaps the most famous exemplar here is found in the writings (homilies) of Gregory of Nyssa, who understood Qohelet's one-sided dialogue with the Divine as a philosophical search for God who can be represented by the Idea of the Good (see Gregory of Nyssa 1993:34). An altogether different sort of Platonic profiling is also attested in more recent research, viewing Qohelet as a character comparable to the Socrates of Plato's dialogues (see Loewenclau 1986:327-338). 
Somewhat more complex is a set of related albeit distinct negative philosophical labels with folk-metaphysical, epistemological and axiological connotations and which have also found their way into this category (e.g. philosophical profiling). The first subcategory is pessimism, sometimes inadvertently used in the popular sense of being psychologically negative rather than in technical philosophical sense of expressing a metaphysical dogma (e.g. Forman 1958:336-343; Kaufmann 1899:389-400; Pedersen 1931:317-370). Secondly, one also encounters research characterised by the attribution of scepticism to Qohelet (e.g. Klopfenstein 1972:97-109; Pfeiffer 1934:100-109). As philosophical profile, this label is often used equivocally in the context of discussions of sceptical theological trends in ancient Israel (e.g. Crenshaw 1980:1-19; Priest 1968:311326). A third related negative philosophical category now somewhat forgotten in the history of research is cynicism (Jastrow 1919; Liebschutz 1920:731-741). Equivocation again occurs, namely Qohelet as cynical both in the popular sense and in the philosophical sense. Fourthly and finally, there is the more recent profiling of Qohelet via the concept of nihilism (e.g. Sekine 1991:3-54).

Somewhat more positive philosophical profiling is also attested in philosophical commentary and has tended to exhibit a folk-metaphysical or folk-epistemological focus. For example, a more neutral stance in this subcategory involves viewing Qohelet as a 'realist' (e.g. Klaaren 1982:123-126; Knopf 1930:195-199). Here, especially, the philosophical jargon is not used in the technical philosophical sense (i.e. regarding the ontological status of, say, universals) but in the popular sense (i.e. of being 'realistic'). This desire to identify an alternative and more upbeat quasi-philosophical vision is particularly prominent in fundamentalist readings where Qohelet is turned into an apologetic philosopher of religion who is interpreted as attempting to discourage atheism by showing how futile life is supposed to be without God. More on this will be said below (see the last category).

\section{Comparative philosophy (ancient)}

Many studies have also compared Qohelet to ancient philosophical traditions and ideas. Though overlapping with the previous category, here one may distinguish two large categories, Greek and Far Eastern. For historical purposes, ancient Near-Eastern comparisons will not be listed here since most scholars comparing elements of Qohelet's 'philosophy' with Egyptian, Mesopotamian and other wisdom traditions viewed their research as comparative religion rather than comparative philosophy. With regard to the types of relations identified, for practical purposes, one may distinguish between claims of direct dependence relations, indirect dependence relations, similar-but-independent-concerns relations and contrasting relations.

As far as comparisons with Greek philosophy are concerned (which was the most popular, see Crenshaw 1983:41-56), these should be distinguished from comparisons with Greek linguistic phenomena and Greek thought in general, including poetry, drama, myth, et cetera. Chronologically, instances of specifically philosophical comparisons include research on Qohelet in relationship to post-Aristotelian philosophy (Palm 1885), to Greek philosophy in general (Lods 1890), to early Greek philosophy (Ranston 1923:160 169, 1925), to pessimistic Greek philosophers (Forman 1957) and to popular philosophy (Braun 1973). There are also alleged relationships with the Greek philosophical doctrine of recurrence (Lohfink 1985:125-149; who lists many alleged parallels), Socrates (Von Loewenclau 1986:327-338) and the concept of 'woman' (Loretz 1992b:245-264). Qohelet has also been located somewhere between Jewish wisdom and Greek philosophy (Schwienhorst-Schonberger 1994; cf. Collins 1997:41). Other comparisons in this category relate Qohelet to the philosophical concept of the middle way (Schwienhorst-Schonberger 1998:181-203), to Greek popular philosophy (Bühlmann 2000) and to Greek conceptions of Being (Crenshaw 2009:41-62).

Not all scholars would call the Far-Eastern parallels necessarily philosophical in genre. Yet as noted above, recent trends have included all wisdom literature under the rubric of (moral or practical) philosophy, following the postmodern trend to decolonise non-Western genres that were disregarded for not being like Greek philosophy (see Davies 2011:145-164; Thompson 1999). In terms of traditions further to the east, we find examples of comparisons with, inter alia, Qohelet's concept of opposites (Horton 1972:1-21), Qohelet and traditions in Thai Buddhism (Lorgunpai 1994:155-162), Qohelet versus the Daoist philosopher Zhuang Zi (Chang $\mathrm{Tzu}$ ) on the concept of death and the perception of the Divine (Lee 1995:69-81), Qohelet and Daoism or the Dao De Jing in general (Heard 1996:65-93), Qohelet compared specifically with the Book of Changes (Horton 2000:79-99) and, finally, in relationship to a variety of Chinese philosophical views on cosmic order (Nigosian 2004:57-67).

\section{Comparative philosophy (modern)}

On comparing Qohelet and modern philosophy, different categories again become readily apparent on a closer assessment of the available literature. Firstly, there is the general trend which simply remarks on the seemingly modern tone or ideas relevant-to-moderns in Qohelet (e.g. Choi 1981:117-118; Lavoie 1995, 1997:143-149; Vogel 1959:82-92; Wills 1973:15-19; Wright 1883). This is generally considered warranted in that some things that ail modernity are often considered to be prefigured in Qohelet.

A second major trend compares Qohelet to existentialist philosophy in the broad sense (e.g. Gordis 1968; James 1984:85-90; Lavoie 1997:147-167). When it comes to specifics, however, by far the most attention has gone into reading Qohelet in relationship to the absurdist philosophy of Albert Camus (see e.g. Berger 2001:141-179; Fox 1986:409427; Michel 1970:22-36; Morgan 2012; Peter 1980:26-43; Schwartz 1986:29-34). On yet other occasions, existential themes are brought to bear, for example alienation (Haden 1987:52-66). Even so, other philosophers have also been 
dragged into the discussion, including Martin Heidegger (see e.g. Aquino 1981; Klopfenstein 1991:97-107). Atypical comparisons also occur. There is, for example, a study on Qohelet and Montaigne (Perry 1993:263-278). Interestingly, only a few comparisons with the arch-pessimist Arthur Schopenhauer is available despite the darkest of philosophers' affinities with Qohelet on the subject of the vanity of existence (e.g. Sawicki 1903; Stock 1962:107-110; Stockhammer 1960:52-78).

A third somewhat fuzzy and underrepresented category is that of post-existentialist comparisons that relate Qohelet to more recent post-modern philosophical schools of thought. In this sparsely populated group, we encounter, inter alia, recourse to structuralism (e.g. Loader 1979), deconstruction (e.g. Barton 1996:226-228; Christianson 1998:425-443; Koosed 2006; Kruger 1996:107-129; Sneed 1997:303-311), and feminism (various), et cetera. Of course, it could be argued that most of these readings are more literary-critical than philosophical in nature, especially given the blurring of the lines between philosophy and literature in the post-modern context. However, even up to only a few years ago, it could still be noted how little has been seen in terms of post-modern approaches making a lasting impression on Qohelet studies (see Bartholomew 2009:31).

\section{Reading via a specific philosophical field or topic}

In many philosophical approaches to Qohelet, we find less of a reading of Qohelet as philosophy per se and more of an emphasis on reading Qohelet in the context of a philosophical discipline or reconstructing Qohelet's assumptions related to a particular philosophical topic (see generally Koprek 2002:283-296). Whilst this often occurs in commentaries on Qohelet on a micro-scale, the studies noted below are examples of a more exclusive and in-depth focus on things philosophical. Again the research gathered here overlaps with that placed in other categories since everything mentioned elsewhere in the discussion can also be located on the philosophical map. Yet once more, the works listed below can in some sense be construed as constitutive of a separate category.

Examples include, alphabetically, axiology (Gericke 2012), divine revelation (Crenshaw 1984:79-92), epistemology (e.g. Bartholomew 2009:passim; Crenshaw 1998:204-224; Fox 1987:137-155; Lohfink 1998:41-59; O’Dowd 2007:65-82; Schellenberg 2002), ethics (Crenshaw 1974:23-55; Kruger 1994:70-84), free will versus determinism (e.g. Kaiser 1989:251-270; Machinist 1995:159-175; Rudman 2001, 2002:97-106), God and philosophy (e.g. Barucq 1976:169189; Crenshaw 2009:41-62; Gericke 2013b), philosophical anthropology (e.g. Lavoie 1996:439-447; Lohfink 1989:201216; Michel 1998:93-111; Willmes 2000; Zimmer 1999), philosophies of death (e.g. Imray 2009; Lavoie 1998:91-107), the meaning of life or existence (e.g. Bickell 1884; Cosser 1955:48-53; Kaiser 1978:3-21; Kreeft 1989; Leiman 1978), the problem of evil or theodicy (e.g. Haupt 1905; Carny
1985:71-81; Kaiser 1987:30-51; Crenshaw 2005:165-176 [and frequently elsewhere]; Sanders 2005:63-77) and time (e.g. Lohfink 1987:236-240; Shefi 1990/1991:144-151; Wallis 1995:316-323).

\section{Philosophical reception and application}

In this category, we are concerned with philosophical reception as well as attempted applied philosophical readings. Here we may distinguish between studies on philosophers' and theologians or biblical scholars' philosophical writings on and incidental philosophical references to or use of Qohelet. As such, this grouping is to be distinguished from historical overviews in general that are not limited to philosophical concerns.

We begin with Bertram (1952:26-29) who argued that, in the LXX, the book of Qohelet was interpreted through Greek philosophical lenses during the translation of certain phrases and concepts, thus making the Septuagint the oldest philosophical reading available (besides the frame narrator). We also find in this category discussions of how Jewish philosophy commenced with Qohelet's pioneering text (e.g. Loretz 1992a:223-244, 1992b:245-264). A general overview with many references to philosophical and antiphilosophical readings can be found in Bartholomew (1998) (history of hermeneutics) and Christianson (2007) (general reception). More specific studies of philosophical reception include, inter alia, how Qohelet was read by Jewish philosophers, for example as in Samuel Ibn Tibbon's commentary (Robinson 2007) and by Ibn Ezra and Rashbam (Gomez-Aranda 2005:235, 258) as well as in more famous mainstream philosophy, for instance in Voltaire (Christianson \& McWilliams 2005:455, 484) and in Spinoza (Hebraizant 2012).

As far as attempts are concerned to show the philosophical actuality or relevance of Qohelet for a contemporary audience (as opposed to mere theological or pastoral readings), a number of studies are available. Again, it is impossible to do justice to this sub-category as most of the literature noted elsewhere somehow tries to do the same thing, albeit as part of larger alternatively focused projects. Examples chosen for this section are, therefore, only a selection of exemplars (e.g. Davidson 1983:184-192; Ellul 1990; Keddie 1991; Kruger 2001:184-195; Lang 1979:109-124; Tamez 1996:28-42).

\section{Denial of philosophy}

In this category are listed both scholarly and popular antiphilosophical readings. Against the backdrop of much antiphilosophical sentiment in biblical scholarship during the relatively recent history of interpretation (especially during the last century with the popular opposition of Hebrew and Greek thinking), many commentators have denied that Qohelet is in any sense philosophical or that it can be related to philosophy at all. Here Qohelet is reconstructed either as a sceptic concerning the value of philosophy (here associated 
with speculative wisdom) or as a theologian warning against the futility of philosophical enterprises. Examples of this include some of the pious anti-intellectual interpreters from a variety of historical periods, especially from the Renaissance and early modern periods, as discussed in Christianson (2007). More recent anti-philosophical approaches are those that rather link the book to psychology (e.g. Zimmerman 1973) or theology (e.g. Whybray 1998). Many Old Testament theologians would, of course, agree and rather choose to link Qohelet to wisdom and to distinguish wisdom literature from philosophy.

This is but the tip of the iceberg. Amongst conservative Christian religious communities, a long history of antiphilosophical readings is attested. Though impossible to mention all the literature attested under this rubric, some typical and popular scholarly examples can be noted (e.g. Caneday 1986:21-56; Harris 1981:115-119; Shank 1974:57-73). As noted earlier, this tradition of reception views Qohelet as a defender of the faith against alleged nihilism, secularism, humanism, intellectualism, and/or atheism. A spectrum exists amongst such readings, that is, from merely seeing Qohelet as taking a stand against a naturalised epistemology to viewing him as providing a reverse-psychological existential argument for why the existence of God should be affirmed for the sake of establishing objective grounds for morality and meaning. Such anti-philosophical perspectives have tended to be motivated by dogmatic-theological rather than exegetical interests.

\section{The relative value of various philosophical perspectives}

At this point the question might be asked: 'So what?' Given all these philosophical perspectives, which of them can be considered most useful? In this regard, though, the question of utility, whilst certainly legitimate, is itself problematic. After all, one may retort with: 'Useful for what purpose(s)?' Whilst this may seem as an evasion of the demand for adjudication so as to establish value, it is not. After all, it really does depend on what the objectives are with which the text is approached vis-à-vis the various philosophical approaches.

For example, if one's primary interest lies in looking for a (philosophical) clarification of the supposed historical sense of Qohelet's ideas, then obviously (for example), outdated theories of Greek parallels as well as problematic anachronistic modern perspectives (e.g. varieties of existentialism) are no longer very useful. Be that as it may, such approaches might still be interesting in the context of comparative philosophy, which deals not only in supposed parallels or dependencies but also in 'identity-by-difference'. By showing how Qohelet both agrees and diverges from a particular philosophy, the meaning of the text is indirectly clarified.

Note, however, that the reference to the totality is to philosophical 'perspectives' rather than to philosophical 'comparisons'. After all, not all readings involve a comparison between Qohelet and some philosophy. Here it may be helpful to distinguish between approaches reading Qohelet as (related to some) philosophy (comparison in one sense) versus philosophical perspectives on the book (in which Qohelet may or may not be seen as philosophical in genre, and the reading may or may not involve comparative philosophy). Which of the two one has in mind will be determinative in trying to gauge the usefulness of a particular philosophical reading.

In sum, there is such a quantity, quality and diversity of philosophical perspectives on Qohelet that it is impossible to point to one as the most useful from a general perspective. By analogy, it is as meaningless as trying to argue which type of biblical criticism is most useful for understanding the biblical texts. That being said, we can say that some philosophical perspective, given its shortcomings relative to its own initial objectives, is now no longer worthy of attention. In addition, given a certain contextual exegetical agenda, we can point to a particular philosophical reading as potentially more relevant to our interests than to others. Even so, this will not show the ultimate value or lack thereof of the particular philosophical perspective but only its merit in relationship to our own contingent readerly objectives.

\section{Conclusion}

In this study, a new typology was provided, mapping the spectrum of distinct albeit overlapping philosophical approaches to Qohelet. Given that philosophical approaches to Qohelet have a long and rich tradition, it is impossible to list all the relevant literature although what was presented should suffice as indication of its quantity and quality. Included in the overview and shown to merit separate mention were the categories of philosophical profiling, relations to ancient philosophy (Greek and Eastern), modern philosophy (especially existentialism), readings in the context of specific philosophical fields or topics, philosophical reception or application and, finally, also the expected denial of philosophy. From this can be concluded that philosophical commentary on the book comes in a multiplicity or plurality of types, contrary to the limited impression sometimes gained from the available literature.

\section{Acknowledgements Competing interests}

The author declares that he has no financial or personal relationship(s) that may have inappropriately influenced him in writing this article.

\section{References}

Anderson, W.H.U., 1998, 'Philosophical considerations in a genre analysis of Qoheleth', Vetus Testamentum 48(3), 289-300. http://dx.doi.org/10.1163/1568 533982722423

Aquino, R., 1981, 'Existential pessimism and the affirmation of God: A philosophical reading of Qohelet', Master's dissertation, Department of Catholic Theology, Saint Thomas Aquinas University.

Bartholomew, C., 1998, Reading Ecclesiastes: Old Testament exegesis and hermeneutical theory, Ignatius Layola Press, Rome. (Analecta Biblia 139). 
Bartholomew, C., 1998, 'Qoheleth in the canon?: Current trends in the interpretation of Ecclesiastes', Themelios 24(3), 4-20.

Bartholomew, C., 2009, Ecclesiastes, Baker Academic Press, Grand Rapids.

Barton, J., 1996, Reading the Old Testament: On method in Biblical Studies, 2nd edn. Darton, Longman \& Todd, London.

Barucq, A., 1976, 'Dieu chez les sages d'Israel', in J. Coppens (ed.), Notion Biblique de Dieu: Le Dieu de la Bible et le Dieu des Philosophes, pp. 169-189, Louvain University Press, Louvain.

Berger, B.L., 2001, 'Qohelet and the exigencies of the absurd', Biblical Interpretation 9(2), 141-179. http://dx.doi.org/10.1163/156851501300139282

Bertram, G., 1952, 'Hebräischer und griechischer Qohelet: Ein Beitrag zur Theologie der hellenistischen Bibel', Zeitschrift für die alttestamentliche Wissenschaft 64(1) 26-49. http://dx.doi.org/10.1515/zatw.1952.64.1.26

Bickell, G.H.W., 1884, Der Prediger [Ecclesiastes] über den Wert des Daseins, Oxford University Press, Oxford.

Braun, R., 1973, Kohelet und die frühhellenistische Popularphilosophie, Walte de Gruyter, Berlin. (Beihefte zur Zeitschrift für die alttestamentliche Wissenschaft 130).

Bühlmann, A., 2000, La structure logique du livre de Qohélet: Ou comment être sage sous les Ptolémées?, Manfred Görg, München. (Biblische Notizen, Beihefte 12).

Caneday, A.B., 1986, 'Qoheleth: Enigmatic pessimist or godly sage', Grace Theological Journal 7(1), 21-56.

Carny, P., 1985, 'Theodicy in the Book of Qohelet', in M. Weinfeld (ed.), Justice and righteousness in Israel and the Nations: Equality and freedom in Ancient Israel in light of social justice in Ancient Near East, pp. 71-81, Magnes Press, Jerusalem.

Choi, J.H., 1981, 'Qohelet's modernity', Theology Digest 29, 117-118.

Christianson, E.S., 1998, 'Qoheleth and the/his self among the deconstructed', in A. Schoors (ed.), Qohelet in the context of wisdom, pp. 425-423, Leuven University Press, Leuven. (Bibliotheca Ephemeridum Theologicarum Lovaniensium 136).

Christianson, E.S., 2007, Ecclesiastes through the centuries, Wiley-Blackwell, London.

Christianson, E. \& McWilliams, T., 2005, 'Voltaire's Precis of Ecclesiastes: A case study in the Bible's afterlife', Journal for the Study of the Old Testament 29(4), 455-484. $\mathrm{http} / / / \mathrm{dx}$.doi.org/10.1177/0309089205054760

Collins, J.J., 1997, Jewish wisdom in the Hellenistic age, Westminster John Knox Press, Louisville. (Old Testament Library, Press).

Cosser, W., 1955, 'The meaning of "life" (Hayyīm) in Proverbs, Job, and Ecclesiastes', Glasgow University Oriental Society Transactions 15, 48-53.

Crenshaw, J.L., 1974, 'The eternal gospel (Eccl 3:11)', in J.L. Crenshaw \& J.T. Willis (eds.), Essays in Old Testament ethics: I Philip Hyatt, in memoriam, pp. 23-55, KTAV Pub House, New York.

Crenshaw, J.L., 1980, 'The birth of scepticism in Ancient Israel', in J.L. Crenshaw \& S. Sandmel (eds.), The divine helmsman: Studies on God's control of human events, Presented to Lou H Silberman, pp. 1-19, Ktav Publishing House, New York.

Crenshaw, J.L., 1983, 'Qoheleth in current research', Hebrew Annual Review 7, 41-56.

Crenshaw, J.L., 1984, A Whirlpool of Torment: Israelite Traditions of God as an Oppressive Presence, Fortress Press, Grand Rapids.

Crenshaw, J.L., 1998, 'Qoheleth's understanding of intellectual inquiry', in A. Schoors (ed.), Qohelet in the context of wisdom, pp. 200-224, Leuven University Press, Leuven. (Bibliotheca Ephemeridum Theologicarum Lovaniensium 136).

Crenshaw, J.L, 2005, Defending. God: Biblical Responses to the Problem of Evil, Oxford University Press, Oxford. http://dx.doi.org/10.1093/0195140028.001.0001

Crenshaw, J.L., 2009, 'Sipping from the cup of wisdom', in P.K. Moser (ed.), Jesus and philosophy: New essays, pp. 41-62, Cambridge University Press, Cambridge.

Davidson, R., 1983, The courage to doubt: Exploring an Old Testament theme, SCM Press, London.

Davies, P.R., 2011, 'Reading the Bible intelligently', Relegere 1, 145-64. http://dx.doi org/10.11157/rsrr1-1-392

Ellul, J., 1990, The reason for being: A meditation on Ecclesiastes, transl. J.M. Hanks, Eerdmans, Grand Rapids.

Forman, C.C., 1957, 'Echoes of ancient pessimistic thought in Ecclesiastes', Ph.D. dissertation, Department of Biblical Studies, Harvard University.

Forman, C.C., 1958, 'Pessimism of Ecclesiastes', Journal of Semitic Studies 3(4), 336-343. http://dx.doi.org/10.1093/jss/3.4.336

Fox, M.V., 1986, 'The meaning of hebel for Qohelet', Journal of Biblical Literature 105(3), 409-427. http://dx.doi.org/10.2307/3260510

Fox, M.V., 1987, 'Qohelet's epistemology', Hebrew Union College Annual 58, 137-155.

Fox, M.V., 1989, Qohelet and his contradictions, Sheffield Academic Press, Sheffield. (JSOT Supplementum 71).

Gammie, J.G, 1985, Stoicism and anti-Stoicism in Qohelet, Hebrew Annual Review 9, 169-187.

Garrett, D.A., 1988, 'Ecclesiastes 7:25-29 and the feminist hermeneutic', Criswell Theological Review 2, 309-321.

Gericke, J.W., 2012, 'Axiological assumptions in Qohelet: A historical-philosophical clarification', Verbum et Ecclesia 33(1), Art. \#515, http://dx.doi.org/10.4102/ ve.v33i1.515

Gericke, J.W., 2013a, 'The love of wisdom in Proverbs 8: A comparative-philosophical clarification', Journal for Semitics 22(2), 343-357.
Gericke, J.W., 2013b, 'Qohelet's concept of deity: A comparative philosophical perspective', Verbum et Ecclesia 34(1), 1-8. http://dx.doi.org/10.4102/ ve.v34i1.743

Gomez-Aranda, 2005, 'Ibn Ezra and Rashbam on Qohelet: Two perspectives in contrast', Hebrew Studies 46, 235-258.

Gordis, R., 1968, Koheleth: The man and his world: A study of Ecclesiastes, Schocken, New York.

Gregory of Nyssa, 1993, Gregory of Nyssa: Homilies on Ecclesiastes, ed. S.G. Hall, Walter De Gruyter, Berlin. http://dx.doi.org/10.1515/9783110873184

Haden, N.K., 1987, 'Qoheleth and the problem of alienation', Christian Scholars Review 17, 52-66.

Harris, R.L., 1981, 'Ecclesiastes: Solomon, the divine philosopher', Presbyterion 7(1/2), 115-119.

Haupt, P., 1905, Koheleth oder Weltschmerz in der Bibel, J. C. Hinrichs, Leipzig.

Heard, R.C., 1996, 'The Dao of Qoheleth: An intertextual reading of the Daode Jing and the Book of Ecclesiastes', Jian Dao 5, 65-93.

Hebraizant, L., 2012, Spinoza's Reading of Ecclesiastes, Warren Montag. http://dx.doi. org/10.1111/j.1468-0378.2012.00515.x

Hohnjec, N., 2002, 'Tri biblijske filozofije zivota: Zivot kao ispraznost (Prop), trpljenje (Job) i ljubav (Pj)', Obnovljeni Zivot 57(3), 333-351.

Horton, E.H., 1972, 'Koheleth's concept of opposites as compared to samples of Greek philosophy and near and far eastern wisdom classics', Numen 19, 1-21.

Horton, E.H., 2000, 'The Hebrew book of changes: Reflections on hakkol hebel and lakkol zeman in Ecclesiastes', Journal for the Study of the Old Testament 90, 79-99.

Imray, K., 2009, 'Qohelet's philosophies of death', Ph.D. thesis, Department of Philosophy Murdoch University.

James, K.W., 1984, 'Ecclesiastes: Precursor of existentialists', The Bible Today 22, 85-90.

Jastrow, M., 1919, A gentle cynic: Being a translation of the Book of Koheleth, commonly known as Ecclesiastes, stripped of later additions: Also its origin, growth, and interpretation, J B Lippincott, Philadelphia.

Kaiser, O., 1978, 'Die Sinnkrise bei Kohelet', in G. Muller (ed.), Rechtfertigung, Realismus, Universalismus in biblischer Sicht, Festschrift für Adolf Koberle zum 80 Geburstag, pp. 3-21, Wissenschaftliche Buchgesellschaft, Darmstadt.

Kaiser, O., 1982, 'Gottesgewissheit und Weltbewusstsein in der frühhellenistischen jüdischen Weisheit', in T. Rendtorff (ed.), Glaube und Toleranz: Das theologische Erbe der Aufklarung, pp. 76-88, Gütersloher Verlagshaus Gerd Mohn, Gütersloh.

Kaiser, O., 1987, 'Schicksal, Leid und Gott: Ein Gesprach mit dem Kohelet, Prediger Salomo', in M. Oeming \& A. Graupner (eds.), Altes Testament und christliche Verkundigung: Festschrift für Antonius H J Gunneweg zum 65 Geburtstag, pp. 30-51, W. Kohlhammer, Stuttgart.

Kaiser, O., 1989, 'Determination und Freiheit beim Kohelet/Prediger Salomo und in der fruen Stoa', Neue Zeitschrift fur systematische Theologie und Religionsphilosophie 31(3), 251-270.

Kaufmann, M., 1899, 'Was Koheleth a sceptic?', The Expositor 9, 389-400.

Keddie, G., 1991, Looking for the good life: The search for fulfilment in the light of Ecclesiastes, Presbyterian and Reformed, Phillipsburg.

Klaaren, M.D., 1982, 'Realism and hope', in A. Greenawalt Abernethy, C. Carlson \& P.A. Carque (eds.), Spinning a sacred yarn: Women speak from the pulpit, pp. 123-126, The Pilgrim Press, New York.

Klopfenstein, M.A., 1972, 'Die Skepsis Des Qohelet', Theologische Zeitschrift 28, 97-109.

Klopfenstein, M.A., 1991, 'Kohelet und die Freude am Dasein', Theologische Zeitschrift 47(2), 97-107.

Knopf, C.S., 1930, 'The optimism of Koheleth', Journal of Biblical Literature 49(2), 195-199. http://dx.doi.org/10.2307/3259110

Koosed, J., 2006, Permutations of Qohelet, T \& T Clark Ltd, London. (Library of Hebrew Bible/Old Testament Studies, vol. 429).

Koprek, I., 2002, 'Filozofijsko razmisljanje o Knijizi propovjednika', Obnovljeni Zivot 57(4), 283-296.

Kreeft, P., 1989, Three philosophies of life: Ecclesiastes - Life as vanity, Job - Life as suffering, Song of Songs - Life as love, Harper, San Francisco.

Kruger, T., 1994, 'Qoh 2:24-26 und die Frage nach dem "Guten” im Qohelet-Buch', Biblische Notizen 72, 70-84.

Kruger, T., 1996, 'Dekonstruktion und Rekonstruktion prophetischer Eschatologie im Qohelet-Buch', in A.A. Diesel, R.G. Lehmann \& E. Otto (eds.), Jedes Ding hat seine Zeit ...': Studien zur israelitischen und altorientalischen Weisheit: Diethelm Michel zum 65 Geburtstag, pp. 107-129, Walter de Gruyter, Berlin. http://dx.doi. Michel zum 65 Geburtstag, pp. 107-1
org/10.1515/9783110813029.107

Kruger, T., 2001, 'Alles Nichts? Zur Theologie des Buches Qohelet', Theologische Zeitschrift 57, 184-195.

Lang, B., 1979, 'Ist der Mensch hilflos?: Das biblische Buch Kohelet, neu und kritisch gelesen', Theologische Quartalschrift 159(2), 109-124.

Lavoie, J.J., 1995, Qohelet: Une Critique Moderne De La Bible, Mediaspaul, Montreal. (Parole D'actualite 2)

Lavoie, J.J., 1996, 'Temps Et Finitude Humaine: Etude De Qohelet IX 11-12', Vetus Testamentum 46(4), 439-447. http://dx.doi.org/10.1163/1568533962581864 
Lavoie, J.J., 1997, 'Critique Cultuelle Et Doute Existentiel: Etude De Qo 4,17-5,6', Studies in Religion/Sciences religieuses 26(2), 147-167.

Lavoie, J.J., 1998, 'La philosophie comme reflexion sur la mort: Etude de Qohelet 7,1-4', Laval Theologique et Philosophique 54(1), 91-107. http://dx.doi. org/10.7202/401136ar

Lee, A.C.C., 1995, 'Death and the perception of the divine in Qohelet and Zhuang Zi', Ching Feng 38(1), 69-81.

Leiman, H.I., 1978, Koheleth: Life and its meaning, Feldheim, Jerusalem

Liebschutz, N., 1920, 'The cynic in the Bible', Methodist Quarterly Review 69(4), 731-741.

Loader, J.A., 1979, Polar structures in the Book of Qohelet, De Gruyter, Berlin (Beihefte zur Zeitschrift für die alttestamentliche Wissenschaft 152). http://dx.doi. org/10.1515/9783110846539

Lods, A., 1890, 'L'Ecclésiaste et la Philosophie Grecque', BA Dissertation, Protestant Theology, Jouve, Paris.

Lohfink, N., 1985, 'Die Wiederkehr des immer Gleichen: Eine frühe Synthese zwischen griechischemund judischem Weltgefühl in Kohelet 1,4-11', Archivo di Filosofia 53 , 125-149.

Lohfink, N., 1987, 'The present and eternity: Time in Qoheleth', Theology Digest 34(3), $236-240$.

Lohfink, N., 1989, 'Koh 1,2 "Alles ist Windhauch": Universale oder anthropologische Aussage', in R. Mosis \& L. Ruppert (eds.), Der Weg zum Menschen: Zur philosophischen und theologischen Anthropologie fur Alfons Deissler, pp. 201216, Herder, Freiburg.

Lohfink, N., 1990, 'Zur Philosophie Kohelets: Eine Auslegung von Kohelet 7,1-10', Bibel und Kirche 45, 20-25.

Lohfink, N., 1998, 'Ist Kohelet's Hbl-Aussage erkenntnistheoretisch gemeint?', in A Schoors (ed.), Qohelet in the context of wisdom, pp. 41-59, Leuven University Press, Leuven. (Bibliotheca Ephemeridum Theologicarum Lovaniensium 136)

Loretz, O., 1992a, 'Anfange judischer Philosophie nach Qohelet 1,1-11 und 3,1-15', Ugarit- Forschungen 23, 223-244.

Loretz, O., 1992b, “"Frau” und griechisch-judische Philosophie im Buch Qohelet (Qoh 7,23-8,1 und 9,6-10)', Ugarit-Forschungen 23, 245-264.

Lorgunpai, S., 1994, 'The books of Ecclesiastes and Thai Buddhism', Asia Journal of Theology 8, 155-162.

Machinist, P., 1995, 'Fate, Miqreh, and reason: Some reflections on Qohelet and Biblical thought', in Z. Zevit, S. Gitin \& M. Sokoloff (eds.), Solving riddles and untying knots: Biblical, epigraphic, and Semitic studies in honor of James C Greenfield, pp. 159-175, Eisenbrauns, Winona Lake.

Michel, D., 1970, 'Humanität Angesichts des Absurden: Qohelet (Prediger) 1,2-3,15' in H. Foerster (ed.), Humanität heute, pp. 22-36, Lutherisches Verlagshaus, Berlin.

Michel, D., 1998, “'Unter der Sonne”: Zur Immanenz bei Qohelet', in A. Schoors (ed.), Qohelet in the context of wisdom, pp. 93-111, Leuven University Press, Leuven. (Bibliotheca Ephemeridum Theologicarum Lovaniensium 136)

Morgan, J.K., 2012, 'The burden of knowing: Camus, Qohelet, and the limitations of human reason', Eleutheria 2, 1-6.

Nigosian, S.A., 2004, 'Biblical and Chinese views on cosmic order', Theological Review 25(2), 57-67.

Nordheimer, I., 1838, 'The philosophy of Ecclesiastes', American Biblical Repository $12(31 / 32), 197-219$.

O'Dowd, R., 2007, 'A chord of three strands: Epistemology in Job, Proverbs and Ecclesiastes', in M. Healy \& R. Parry (eds.), The Bible and epistemology, Paternoster, Colorado Springs.

Palm, A., 1885, Kohelet und die nach-aristotelische Philosophie, Hogrefe, Mannheim.

Pedersen, J., 1931, 'Scepticisme Israelite', Revue d'histoire et de philosophie religieuses $10,317-370$

Perry, T.A., 1993, 'Montaigne y Kohelet, sobre las vanidades de este mundo', hacia una filosofía sefardí Actes del Simposi Internacional sobre Cultura Sefardita, pp. 263-278.

Peter, C.B., 1980, 'In defence of existence: A comparison between Ecclesiastes and Albert Camus', Bangalore Theological Forum 12, 26-43.

Pfeiffer, R.H., 1934, 'The peculiar scepticism of Ecclesiastes', Journal of Biblical Literature 53(2), 100-109. http://dx.doi.org/10.2307/3259877

Priest, J., 1968, 'Humanism, scepticism and pessimism in Israel', Journal of the American Academy of Religion 36, 311-326. http://dx.doi.org/10.1093/jaarel/ $\mathrm{XXXVI.4.311}$

Ranston, H., 1923, 'Koheleth and the early Greeks', Journal of Theological Studies 24 160-169. http://dx.doi.org/10.1093/jts/os-XXIV.94.160
Ranston, H., 1925, Ecclesiastes and the early Greek wisdom literature, Epworth, London.

Richter, H.F., 1998, 'Kohelet: Philosoph und Poet', in A. Schoors (ed.), Qohelet in the context of wisdom, pp. 435-449, Leuven University Press, Leuven. (Bibliotheca Ephemeridum Theologicarum Lovaniensium 136).

Robinson, J.T., 2007, Samuel Ibn Tibbon's commentary on Ecclesiastes: The book of the soul of man, Tubingen, Mohr Siebeck.

Rudman, D., 2001, Determinism in the book of Ecclesiastes, Sheffield Academic Press, Sheffield. (Journal for the Study of the Old Testament Supplement 316).

Rudman, D., 2002, 'Determinism and anti-determinism in the book of Koheleth', Jewish Bible Quarterly 30(2), 97-106.

Sanders, J.T., 2005, 'Wisdom, theodicy, death, and the evolution of intellectual traditions', Journal for the Study of Judaism in the Persian, Hellenistic and Roman Period 36(3), 263-277. http://dx.doi.org/10.1163/1570063054377697

Sawicki, F., 1903, Der Prediger, Schopenhauer und Ed. v. Hartmann oder biblischer und moderner Pessimismus, Fuldaer Actiendruckerei, Fulda.

Schellenberg, A., 2002, Erkenntnis als Problem: Qohelet und die alttestamentliche Diskussion um das menschliche Erkennen, Vandenhoeck \& Ruprecht, Gottingen. (Orbis Biblicus Et Orientalis 188).

Schwartz, M.J., 1986, 'Koheleth and Camus: Two views of achievement', Judaism 35(1), 29-34.

Schwienhorst-Schonberger, L., 1994, 'Nicht im Menschen grundet das Gluck' (Koh 2 24): Kohelet im Spannungsfeld jüdischer Weisheit und hellenistischer Philosophie, Herder, Freiburg. (Herders Biblische Studien 2).

Schwienhorst-Schonberger, L., 1998, 'Via Media: Koh 7,15-18 und die griechischhellenistische Philosophie', in A. Schoors (ed.), Qohelet in the context of wisdom, pp. 181-203, Leuven University Press, Leuven. (Bibliotheca Ephemeridum pp. 181-203, Leuven University
Theologicarum Lovaniensium 136).

Sekine, S., 1991, 'Qohelet als Nihilist', Annual of the Japanese Biblical Institute 17 3-54.

Shank, H.C., 1974, 'Qoheleth's world and life view as seen in his recurring phrases', Westminster Theological Journal 37, 57-73.

Shefi, E., 1990/1991, 'Ecclesiastes' treatment of the concept of time', Beth Mikra 36 144-51.

Sneed, M., 1997, 'Qohelet as "deconstructionist"', Old Testament Essays 10(1), 303-311.

Sneed, M., 2012, The politics of pessimism in Ecclesiastes: A social-science perspective, Society of Biblical Literature, Atlanta.

Stefani, P., 1995, 'Risonanze filosofiche del Qohelet', Humanitas 50(3), 393-409.

Stock, G., 1962, 'Nochmals Kohelets Pessimismus', Schopenhauer-Jahrbuch 42, 107-110.

Stockhammer, M., 1960, 'Kohelets Pessimismus', Schopenhauer-Jahrbuch 41, 52-78.

Tamez, E., 1996, 'Living wisely in the midst of absurdity: Meditations from the book of Ecclesiastes', Church \& Society 86, 28-42.

Thompson, T.L., 1999, The Bible in history: How writers create a past, Pimlico, London.

Tyler, T., 1899, Ecclesiastes: An introduction to the book, an exegetical analysis and a translation, with notes, D. Nutt, London.

Vogel, D., 1959, 'Koheleth and the modern temper', Tradition 2(1), 82-92.

Von Loewenclau, I., 1986, 'Kohelet und Sokrates: Versuch eines Vergleiches', Zeitschrift fur die alttestamentliche Wissenschaft 98(3), 327-338. http://dx.doi. org/10.1515/zatw.1986.98.3.327

Wallis, G., 1995, 'Das Zeitverstandnis des Predigers Salomo', in M. Weippert \& S. Timm (eds.), Festgabe für Herbert Donner zum 16 Februar 1995, pp. 316-323, Harrassowitz, Wiesbaden. (Agypten und Altes Testament 30).

Whybray, R.N., 1998, 'Qohelet as theologian', in A. Schoors (ed.), Qohelet in the context of wisdom, pp. 239-265, Leuven University Press, Leuven. (Bibliotheca Ephemeridum Theologicarum Lovaniensium 136).

Willmes, B., 2000, Menschliches Schicksal und ironische Weisheitskritik im Koheletbuch: Kohelets Ironie und die Grenzen der Exegese, Neukirchener Verlag, Neukirchen-Vluyn. (Biblisch-Theologische Studien 39).

Wills, J.C., 1973, 'The deserted village, Ecclesiastes, and the Enlightenment', Enlightenment Essays 4(3/4), 15-19.

Wright, C.H.H., 1883, The book of Koheleth considered in relation to modem criticism and to the doctrines of modem pessimism, with a critical and grammatical commentary, and a revised translation, Hodder \& Stoughton, London.

Zimmer, T., 1999, Zwischen Tod und Lebensgluck: Eine Untersuchung zur Anthropologie Kohelets, Walter de Gruyter, Berlin. (Beiheft zur Zeitschrift für die alttestamentliche Wissenschaft 286). http://dx.doi.org/10.1515/9783110813357

Zimmerman, F., 1973, The inner world of Qohelet, KTAV, New York. 